\title{
Beban Pencemaran BOD dan Karakteristik Oksigen Terlarut di Sungai Brantas Kota Malang
}

\author{
Novia Lusiana ${ }^{1}$, Bambang Rahadi Widiatmono², dan Hana Luthfiyana ${ }^{3}$ \\ 1Program Studi Teknik Lingkungan, Fakultas Teknologi Pertanian, Universitas Brawijaya, Malang, 65145, \\ Indonesia; email: novialusiana@ub.ac.id \\ 2Program Studi Teknik Lingkungan, Fakultas Teknologi Pertanian, Universitas Brawijaya, Malang, 65145, \\ Indonesia; email: jbrahadi@ub.ac.id \\ ${ }^{3}$ Mahasiswa Teknik Lingkungan, Fakultas Teknologi Pertanian, Universitas Brawijaya, Malang, 65145, Indonesia; \\ email: luthfiyanahana@gmail.com
}

\begin{abstract}
ABSTRAK
Sungai Brantas memiliki fungsi penting bagi provinsi Jawa Timur, $60 \%$ pengairan lahan produksi beras berasal dari aliran sungai ini. Observasi lapang menunjukkan bahwa terdapat banyak bangunan rumah mendekati area sungai bahkan sampai melewati batas, hal ini juga terjadi khususnya di area Kota Malang. Rekaman laporan indeks kualitas air di Jawa Timur Tahun 2015 tercatat berada di angka 52.51 dengan status sangat rendah dan terus menurun dengan angka 50.75 pada tahun 2016 dengan status yang waspada. Berdasarkan kondisi diatas sangat penting untuk memonitor kualitas air dan menentukan kapasitas sungai dalam menerima polusi secara berkelanjutan. Metode atau model yang dapat digunakan untuk memprediksi kualitas air secara simultan sepanjang sungai adalah Qual2E. Aplikasi ini menghitung kestabilan profil air permukaan dan mensimulasikan perubahaan pada kondisi aliran sepanjang aliran sungai. Tujuan dari studi ini adalah mensimulasikan kondisi kualitas air berdasarkan parameter BOD dan DO dan menentukan kapasitas beban polusi. Hasil simulasi dengan model Qual2E pada parameter BOD dan DO dengan hasil validasi didapatkan bahwa model dapat diterima karena $\mathrm{x}^{2}$ hitung $<\mathrm{x}^{2}$ tabel yaitu pada BOD sebesar 2.456 dan $\mathrm{x}^{2}$ hitung pada DO sebesar 1.439 dengan nilai $\mathrm{R}^{2}$ masing-masing parameter sebesar 0.7424 dan 0.6439, sehingga terdapat kedekatan korelasi antara hasil lapang dengan model yang dilakukan. Perhitungan beban pencemaran pada Sungai Brantas menunjukkan bahwa titik 6 yang terletak pada Kecamatan Blimbing dan titik 9 pada Kecamatan Kedungkandang menerima beban pencemaran yang melebihi daya tampung atau beban maksimum yang dikehendaki, Perlu perhatian khusus untuk pembuangan limbah yang ada di perairan pada titik tersebut agar dapat ditanggulangi dengan cepat dan tidak memperburuk kondisi yang ada. Penerapan peraturan Menteri Lingkungan Hidup No. 01 Tahun 2010 tentang tata laksana pengendalian pencemaran air perlu dimonitoring.
\end{abstract}

Kata kunci: BOD, Daya tampung, DO, Polusi, Qual2E

\section{ABSTRACT}

The Brantas River has an important function for East Java, $60 \%$ of rice production comes from rice fields along this river flow. Field observations show that there is a lot of housing construction approaching the river even though it is not on the river border, especially in Malang City. Recorded in the Environmental Management Quality Index Report The water quality index in East Java in 2015 was recorded at 52.51 with the status of "Very Poor" and experienced a decline in quality to 50.75 in 2016 and with a status close to "Alert". Based on the above conditions it is necessary to monitor water quality and determine the capacity of the Brantas River in Malang continuously. The method or modeling with Qual2E is one of the applications used for river pollution modeling which can be used to simulate pollutant indicators along the river flow. The purpose of this study is to simulate water quality conditions based on BOD and DO parameters and determine the capacity of the pollution load. Validation of Qual2E's simulation results shows that the result can be accepted due to $x^{2}$ calculated value $>x^{2}$ table either on BOD or DO parameter. Moreover, the correlation analysist $\mathrm{R}^{2}$ between them shows the number 0.7424 for BOD and 0.6439 for DO. It means that the simulaition of Qual2E has close relation with the actual condition. According to the calculation of pollution load capacity, Belimbing and Kedungkandang have received the maximum pollutant load than their capacity. The government should be concerned for wastewater disposal in these areas in order to prevent declining of water quality. Implementaion of the ministry of environment rule about water pollution controling procedure needs to be monitored.

Keywords: BOD, Capacity, DO, Load Pollution, Qual2E

Citation: Lusiana, N., Widiatmono, B.R., dan Luthfiyana, H. (2020). Beban Pencemaran BOD dan Karakteristik Oksigen Terlarut di Sungai Brantas Kota Malang. Jurnal Ilmu Lingkungan, 18(2), 354-366, doi:10.14710/jil.18.2.354-366

\section{Pendahuluan}

Sungai Brantas adalah salah satu sungai di Indonesia yang berada di Jawa Timur. Sungai Brantas merupakan sungai terpanjang kedua di Pulau Jawa setelah Sungai Bengawan Solo. Sungai Brantas mempunyai DAS seluas $\pm 12,000 \mathrm{~km}^{2}$ atau $1 / 4$ dari luas 
Provinsi Jawa Timur. Mata air Sungai Brantas terletak di Desa Sumber Brantas, Kecamatan Bumiaji, Kota Batu yang berasal dari simpanan air Gunung Arjuno. Dari Batu, DAS Brantas mengalir ke Malang, Blitar, Tulungagung, Kediri, Jombang, Mojokerto. Panjang Sungai Utama $320 \mathrm{~km}$, mengalir melingkari gunung berapi yang masih aktif, yaitu Gunung Kelud. Potensi air permukaan pertahun rata-rata 12 miliar $\mathrm{m}^{3}$, potensi yang dimanfaatkan sebesar 2.6-3.0 miliar $\mathrm{m}^{3}$ per tahun. Ketersediaan air hujan dapat dihitung dari ketersediaan air sungai berdasarkan curah hujan mencapai 10,361 liter/detik, mengalami peningkatan $37.5 \%$ dari keadaan kemarau. Sungai Brantas memiliki fungsi yang penting bagi Jawa Timur mengingat $60 \%$ produksi padi berasal dari areal persawahan di sepanjang aliran sungai ini (Fahmi et al, 2018).

Salah satu anak Sungai Brantas adalah Sungai Metro dan merupakan sungai yang memiliki kontribusi besar terhadap kualitas air Sungai Brantas di Kota Malang. Sungai Metro mengalir di Kota Malang dan alirannya berakhir di Kecamatan Kepanjen, Kabupaten Malang. Pemanfaatan Sungai Metro oleh masyarakat yang ada di sekitar sungai adalah untuk mendukung kehidupan sehari-hari seperti mandi, cuci dan kakus (MCK) serta tempat pembuangan air limbah dari aktivitas rumah tangga. Peningkatan pemanfaatan lahan di sekitar Sungai Metro tentunya akan berdampak langsung terhadap perubahan kualitas air Sungai Metro. Pemanfaatan lahan sebagai pemukiman, industri dan pertanian di sekitar Sungai Metro memberikan kontribusi dalam meningkatkan jenis polutan yang masuk ke Sungai Metro (Mahyudin et al, 2015). Berkembangnya kegiatan penduduk di sepanjang aliran sungai Brantas dapat berpengaruh terhadap kualitas airnya, karena limbah yang dihasilkan dari kegiatan penduduk tersebut dibuang langsung ke sungai. Semakin tinggi aktivitas domestik dan industri di sepanjang sungai, maka akan semakin signifikan terjadi perubahan kualitas air (Handayani et al, 2001).

Kepadatan penduduk Kota Malang yang meningkat setiap tahunnya dapat mempengaruhi kualitas dari Sungai Brantas. Kota Malang terdapat pada ketinggian 399-662.5 m diatas permukaan laut dan memiliki luas sekitar $124,400 \mathrm{Km}^{2}$ dengan jumlah penduduk sekitar 800,000-an warga pada tahun 2018. Kepadatan penduduk Kota Malang dapat mencapai 5000 hingga 12,000 jiwa per $\mathrm{Km}^{2}$ dengan pertumbuhan sebesar 3.9\% per-tahun. (Yulianti, 2011). Panjang sungai utama Brantas Kota Malang adalah $12.94 \mathrm{~km}$ yang mengalir sepanjang Kota Malang dari arah Utara ke Selatan (pada Gambar 1). Apabila terjadi penurunan kualitas air di sepanjang sungai ini tentunya area yang berdampak adalah Kelurahan Sumbersari dengan jumlah penduduk 18405 jiwa, Kelurahan Dinoyo dengan jumlah penduduk 17168 jiwa, Kelurahan Tlogomas dengan jumlah penduduk 19826 jiwa, Kelurahan Sukun dengan jumlah penduduk 9041 jiwa dan Kelurahan Kedungkandang dengan jumlah penduduk 17513 jiwa. Total jumlah masyarakat yang terdampak dengan adanya penurunan kualitas air Sungai Brantas Kota Malang sebesar 81953 jiwa atau 9.4\% dari total masyarakat Kota Malang.

Pemantauan kualitas air Sungai Brantas perlu dilakukan guna mengetahui kualitas air yang ada. Tercatat pada Laporan Indeks Kualitas Pengelolaan Lingkungan Hidup Propinsi Jawa Timur di tahun 2016, kualitas air di Jawa Timur pada tahun 2015 tercatat dengan status sangat kurang dan mengalami penurunan kualitas pada tahun 2016 dengan status sangat kurang hingga mendekati waspada. Penurunan kualitas air ini harus menjadi perhatian khusus mengingat pentingnya peran air untuk sarana kehidupan sehari-hari.

Berdasarkan penelitian Fajaruddin et al, 2018 tentang penentuan daya tampung beban pencemaran ruas Kota Malang menunjukkan nilai beban pencemaran paling besar terdapat pada reach kedua yaitu $609.846 \mathrm{~kg} / \mathrm{hari}$ untuk TSS, $152.669 \mathrm{~kg} / \mathrm{hari}$ untuk BOD, dan $995.976 \mathrm{~kg} / \mathrm{hari}$ untuk COD. Kemudian nilai daya tampung paling tinggi untuk semua parameter terletak di reach kedua sebesarr $584.340 \mathrm{~kg} / \mathrm{hari}$ untuk TSS, $127.164 \mathrm{~kg} / \mathrm{hari}$ untuk BOD, dan $910.958 \mathrm{~kg} / \mathrm{hari}$ untuk COD.

Pada Peraturan Gubernur Jawa Timur Nomor 61 Tahun 2010 Tentang Penetapan Kelas Air Pada Air Sungai, Sungai Brantas pada peraturan yang disebutkan diatas yang berada di Kota Malang ditetapkan pada klasifikasi mutu air yaitu termasuk dalam air kelas II sebagai air yang digunakan untuk parasana/sarana rekreasi air, pembudidayaan ikan air tawar, peternakan, air untuk mengairi pertanaman, dan atau peruntukan lain yang mempersyaratkan mutu air yang sama dengan kegunaan tersebut. Upaya pengelolaan kualitas air pada sungai antara lain dengan menetapkan daya tampung sungai dan menetapkan peruntukan sungai yang disertai dengan penerapan baku mutu perairan. Daya tampung sungai atau daya tampung beban pencemaran sungai adalah kemampuan air pada sungai untuk menerima masukkan beban pencemaran tanpa mengakibatkan air sungai menjadi tercemar.

Pemantauan kualitas air dan penentuan daya tampung beban pencemaran sebagai upaya pengelolaan kualitas air dapat menggunakan model Qual2E. Qual2E adalah salah satu aplikasi pemodelan pencemaran sungai yang dapat digunakan untuk mensimulasikan indikator pencemar sepanjang aliran sungai. Aplikasi Qual2E dapat memperlihatkan keseimbangan dari oksigen terlarut dengan memasukkan sumber dan ketentuan terlarut seperti unsur ketentuan aliran arus $\left(\mathrm{m}^{3} / \mathrm{s}\right)$, panas yaitu ketentuan suhu $\left({ }^{\circ} \mathrm{C}\right)$ dan material dalam konsentrasi (mg/L) pada perhitungan kesetimbangan masa (mass balance) dan juga digunakan untuk mengukur masukan polutan dari nonpoint sources, menentukan sumber polutan, perhitungan fosfor dan mengestimasi kondisi alamiahnya (Parveen et al, 2016). Berdasarkan fungsi dan penjelasan aplikasi 
Qual2E tersebut, aplikasi Qual2E dapat digunakan sebagai metode atau pemodelan untuk melakukan pemantauan kualitas air dan penentuan daya tampung beban pencemaran sebagai upaya pengelolaan kualitas air.

Penelitian daya tampung beban cemaran di Sungai Babon dengan judul Model Identifikasi Daya Tampung Beban Cemaran Sungai Dengan Qual2E (Studi Kasus Sungai Babon) merupakan salah satu penelitian terdahulu yang mengangkat topik model Qual2E. Sungai Babon sendiri berada di Jawa Tengah yaitu di Kabupaten Semarang, Kota Semarang dan Kabupaten Demak. Dengan menggunakan metode Qual2E, penelitian akan mendapatkan model dan dapat menyimpulkan simulasi penurunan beban pencemaran menggunakan model yang dihasilkan tersebut. Model Qual2E dipilih karena dapat mensimulasi suatu perairan dengan interaksi lingkungan yang berhubungan dengan fotosintesis, simulasi dengan berbagai macam nutrient dan dengan oksigen terlarut. Simulasi tersebut dapat dilakukan pada aliran steady dan unsteady. Model tersebut berupa model kualitas air yang dapat digunakan untuk menggambarkan obyek-obyek hubungan dan resoin antar obyek dan dari sistem alam yang merupakan fungsi dari Biologi, Kimia, Klimatologi, Hidrologi dan Hidrolika. Penggunaan model Qual2E dalam simulasi penurunan beban pencemaran dapat memberikan simulasi penurunan beban pencemaran, maka daya tampung beban pencemaran Sungai Babon dapat ditingkatkan dengan cara menurunkan beban pencemaran dari sumber-sumber pencemar yang ada di sekitar Sungai Babon (Wiwoho, 2005).

Penelitian Damarani et al, 2009 tentang penggunakan software Qual2E untuk kajian kualitas air menunjukkan bahwa Hasil simulasi analisis kualitas air menunjukkan kecenderungan kurva BOD semakin menurun seiring dengan pertambahan jarak sedangkan nilai DO fluktuaktif. Konsentrasi BOD dan DO pada lokasi penelitian menunjukkan angka yang sudah melebihi baku mutu Perda setempat yang menyebabkan kualitas ekosistem menurun.

Penelitian kedua dilakukan oleh Utama (2015), yaitu tentang daya tampung beban pencemaran sungai dengan judul Penentuan Daya Tampung Beban Pencemaran BOD dan Fecal Coliform Sungai Plumbon Kota Semarang Dengan Software Qual2E. Penelitian ini memuat Sungai Plumbon sebagai sungai utama dalam DAS Garang yang terletak di Kota Semarang, menggunakan dua parameter yaitu BOD dan fecal coliform karena Sungai Plumbon berada di daerah dekat dengan pemukiman. Maka dari itu aktivitas yang dilakukan oleh masyarakat dapat berpotensi meningkatkan parameter tersebut. Penelitian ini menggunakan software Qual2E untuk mengetahui daya tampung beban pencemaran yang ada di Sungai tersebut.

Tujuan penelitian ini adalah menentukan pola penurunan kualitas air Sungai Metro Kota Malang berdasarkan parameter BOD dan DO menggunakan aplikasi Qual2E, menentukan beban pencemaran yang diterima Sungai Metro akibat aktivitas masyarakat disekitarnya serta menguji performasi simulasi pemodelan Qual2E dalam memodelkan kualitas air.

\section{Metode Penelitian \\ 2.1. Lokasi Penelitian}

Penelitian dilaksanakan di Sungai Brantas yang melewati Kota Malang, dengan pembagian sampel berdasarkan sumber pencemar (point source dan non point source) yang masuk ke Sungai Brantas Kota Malang. Terdapat beberapa jenis sumber pencemar di sepanjang Sungai Brantas Kota Malang yaitu berupa limbah domestik, limbah pertanian, limbah rumah sakit dan limbah industri. Pemilihan jenis kegiatan sebagai sumber pencemar didasarkan atas kategori kegiatan yang memiliki kontribusi besar dalam mengahasilkan jumlah limbah cair. Berdasarkan identifikasi jenis kegiatan di Kota Malang, maka peneliti menentukan jenis kegiatan yang dipilih sebagai sumber pencemar terdiri dari 1) Rumah Sakit dengan alasan limbah cair yang dihasilkan relatif memiliki kandungan berbahaya, 2) Kegiatan industri, mengingat banyaknya industri di Kota Malang, maka untuk mereduksi jumlah sumber pencemar maka hanya industri yang termasuk dalam kategori industri besar yang memiliki jumlah tenaga kerja lebih dari $100,3)$ Pemukiman, area yang dipilih adalah area perbatasan Kecamatan Sukun (area berpenduduk padat yang didalamnya terdapat aktivitas mall, pasar dan perkantoran) dan Kedungkandang untuk menilai peran limbah domestik dalam penurunan kualitas air Sungai Metro, 4) Pertanian, area yang dipilih yang masih memiliki aktivitas pertanian yaitu di Kecamatan Kedungkandang. Tabel 1 merupakan daftar industri dan rumah sakit yang akan digunakan sebagai lokasi sumber pencemar pada penelitian ini, Gambar 1 merupakan sebaran lokasi sumber pencemar.

Penentuan titik sampel merupakan tahapan yang paling penting dalam upaya monitoring kualitas air sungai. Menurut Mahfud, et al (2014) pertimbangan pertimbangan yang digunakan dalam pengambilan sampel air sungai yaitu 1) sumber air alamiah, yaitu lokasi yang belum pernah atau masih sedikit mengalami pencemaran, 2) sumber air tercemar, yaitu lokasi yang telah mengalami perubahan atau di bagian hilir dari sumber pencemar dan 3) sumber air yang dimanfaatkan, yaitu lokasi penyadapan/ pemanfaatan. Penentuan titik sampel yang digunakan dalam penelitian ini yaitu pada pertimbangan yang pertama (a). Pertimbangan tersebut yaitu limbah diambil pada lokasi yg mewakili seluruh karakteristik limbah dan kemungkinan pencemaran yg timbul. Hasil pemilihan lokasi pengambilan sampel dapat dilihat pada Gambar 1. 
Tabel 1. Data sumber pencemar sungai Brantas kota Malang

\begin{tabular}{|c|c|c|c|}
\hline No & Nama & Bidang & Lokasi \\
\hline 1 & Indana Paint & Industri Cat & Il. Laksda Adi Sucipto No. 456, Malang \\
\hline 2 & Bronson Prima & Indutsri Makanan (Permen) & Jl. Tenaga 8, Blimbing, Malang \\
\hline 3 & HM Sampoerna & Industri Rokok & Jl. Industri Barat, 2, Malang \\
\hline 4 & Bintang Terang & Industri Plastik & Jl. Letjen S. Parman IV, Blimbing \\
\hline 5 & Nitradi Wahyu Cemerlang & Industri Plastik & Jl. S.priyo Sudarmo, 33, Malang \\
\hline 6 & PR AA & Industri Rokok & Jl. M. Sungkono RT 2/RW2, Malang \\
\hline 7 & Surya Sejahtera & Industri Rokok & Jl. Mayjen Sungkono, Malang \\
\hline 8 & Usaha Loka & Industri Plastik & Jl. Peltu Sujono, Malang \\
\hline 9 & Bentoel Prima & Industri Rokok & Jl. Niaga 2, Malang \\
\hline 10 & PT Gandum & Industri Rokok & Jl. Mulyosari, Malang \\
\hline 11 & PT Asia & Industri Rokok & Jl. Mulyosari 15, Malang \\
\hline 12 & PT Banyu Biru & Industri Rokok & Jl. A. R. Hakim 2, Malang \\
\hline 13 & RS UMM & Rumah Sakit & Jl. Raya Tlogomas No. 45, Malang \\
\hline 14 & RSUD Kota Malang & Rumah Sakit & Jl. Rajasa No. 27, Kedungkandang \\
\hline 15 & RS Panti Nirmala & Rumah Sakit & Jl. Kebalen Wetan No. 2-8, Malang \\
\hline 16 & RS Aisyiyah & Rumah Sakit & Jl. Sulawesi 16, Malang \\
\hline 17 & RS Panti Waluyo & Rumah Sakit & Jl. Nusakambangan No. 56, Malang \\
\hline 18 & RST Soepraoen & Rumah Sakit & Jl. Sudanco Supriadi No. 22 \\
\hline 19 & RS Syaiful Anwar & Rumah Sakit & Jl. Jaksa Agung Suprapto No. 2 \\
\hline 20 & Pemukiman & Kegiatan Domestik & Kelurahan Kotalama \\
\hline 21 & Sawah & Kegiatan Pertanian & Kelurahan Kedungkandang \\
\hline
\end{tabular}

Sumber data Dinas Perindustrian Kota Malang, 2019

Total lokasi pengambilan sampel pada penelitian ini adalah 12 titik dengan mempertimbangkan beberapa titik yang dapat mewakili beberapa sumber pencemar yang terpilih. Lokasi sampel tersebut adalah sungai yang berada di belakang Rumah Sakit Universitas Muhammadiyah Malang (T1), sungai belakang kampus UNISMA (T2), sungai berlakasi di Panjaitan (T3), sungai yang berlokasi dibelakang RS Syaiful Anwar (T4), lokasi sungai dibelakang pabrik Indana Paint (T5), lokasi sungai yang mewakili sumber pencemar industri dari Kecamatan Belimbing (T6), lokasi sungai dekat pabrik Banyu Biru (T7), lokasi sungai dibawah Jembatan Kebalen (T8), lokasi sungai didekat Rumah Sakit Umum Daerah Kota Malang (T9), lokasi sungai dekat pasar Gadang (T10), lokasi sungai dekar RS Soepraoen (T11) dan lokasi dekat daerah Bandulan (T12).

\subsection{Pengambilan Sampel}

Pengambilan sampel dilakukan pada tanggal 9 Agustus 2019 dan dilakukan sebanyak tiga kali dengan menentukan tiga titik. Waktu pengambilan sampel dipilih atas dasar kondisi musim kemarau untuk mendapatkan gambaran terburuk yang sebenarnya dari keadaan sungai satat debit air sungai masih relative kecil. Pengambilan sampel dilakukan secara sampel sesaat (grab sampling) yaitu sampel diambil pada waktu - waktu tertentu dan sampel tersebut sudah dapat mewakili limbah atau badan air secara keseluruhan. Pengambilan sampel dilakukan sebanyak tiga ulangan dimana menggunakan tiga titik pada masing-masing titik pengambilan sampel. Tiga titik sampel diambil sesuai dengan SNI 6969.57:2008 yaitu di sisi kiri, kanan dan tengah badan sungai dengan kedalaman 0.5 dari kedalaman air sungai. Hal tersebut dilakukan untuk mengetahui gambaran yang sebenarnya dari keadaan sungai. Tata cara pengambilan sampel sesuai dengan SNI 037016-2004 yaitu tata cara pengambilan contoh dalam rangka pemantauan kualitas air pada suatu daerah pengaliran sungai.

Perlakuan pengawetan sampel air dengan menyimpan sampel air pada cool box dengan tujuan menghindarkan sampel dari pencahayaan luar dan memastikan karakteristik sampel tidak berubah, pada penelitian ini sampel diserahkan ke laboratorium lingkungan di hari yang sama. Tata cara pengambilan sampel ini dikhususkan bagi sampel air yang akan diuji kualitas airnya secara fisik dan kimia, parameter yang digunakan dalam penelitian ini terdiri dari suhu, pH, BOD, COD, DO, TSS, Nitrat (NO3), Amonia (NH3), Phospat (PO4) dan Coli Tinja.

Pengambilan data lain terkait dengan morfologi sungai adalah dimensi sungai dan kecepatan aliran air. Dimensi sungai yang diukur meliputi lebar dan kedalaman sungai dengan menggunakan meteran, tujuan pengukuran dimensiadalah untuk menghitung debit air sungai. Selanjutnya untuk pengukuran kecepatan air menggunakan alat current meter pada lokasi yang sama dengan titik pengambilan sampel.

\subsection{Penentuan Kualitas Air}

Parameter yang digunakan dalam penelitian ini meliputi suhu, pH, BOD, COD, DO, TSS, Nitrat (NO3), Amonia (NH3), Phospat (PO4) dan Coli Tinja. Parameter tersebut dapat diketahui kadarnya melalui pengujian sampel air, metode pengujuan sampel mengikuti Standar Nasional Indonesia yang digunakan oleh Laboratorium Lingkungan milik Perum Jasa Tirta I Kota Malang. Tabel 2 menunjukkan metode pengujian yang digunakan oleh Perum Jasa Tirta I dalam menentukan kadar setiap parameter yang terkandung pada sampel air. 


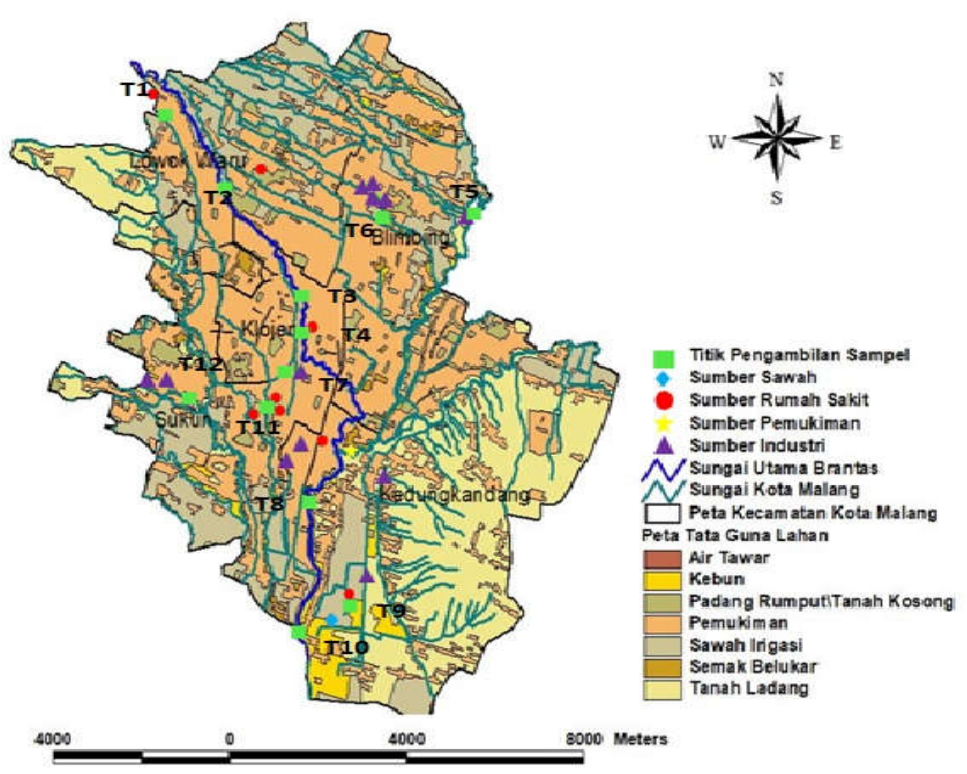

Gambar 1 Peta titik pengambilan sampel sungai Brantas Kota Malang

Tabel 2. Metode pengujian kualitas air

\begin{tabular}{lll}
\hline \multicolumn{1}{c}{ Parameter } & \multicolumn{1}{c}{ Metode Pengujian } & \multicolumn{1}{c}{ Referensi } \\
\hline Temperatur & Termometri & SNI 06-6989. 23-2005 \\
\hline pH & pH meter & SNI 06-6989.11-2004 \\
\hline DO & Yodometri & SNI 06-6989.14-2004 \\
\hline BOD & APHA 5210 B-1998 & SNI 6989. 72: 2009 \\
\hline COD & Spektrofotometri & SNI 6989.2: 2009 \\
\hline TSS & Gravimetri & SNI 06-6989.3-2004 \\
\hline Nitrat $\left(\mathrm{NO}_{3}\right)$ & Spektrofotometri UV & SNI 6989. 79: 2011 \\
\hline Ammonia $\left(\mathrm{NH}_{3}\right)$ & APHA 4500-NH3 F2005 & SNI 06-6989.30-2005 \\
\hline Phosphat Terlarut $\left(\mathrm{PO}_{4}\right)$ & Spektrofotometri & SNI 06-6989.31-2005 \\
\hline Coli Tinja & Tabung Ganda & SNI 01-2332.1-2006 \\
\hline
\end{tabular}

Sesuai dengan Peraturan Gubernur Jawa Timur Nomor 61 Tahun 2010 Tentang Penetapan Kelas Air Pada Sungai, Sungai Brantas Kota Malang ditetapkan dalam kelas air golongan II. Dimana pada penjelasan PP No. 82 Tahun 2001, kelas air adalah peringkat kualitas air yang dinilai masih layak untuk dimanfaatkan bagi peruntukan tertentu. Kelas II adalah air yang peruntukannya dapat digunakan untuk prasarana/sarana rekreasi air, pembudidayaan ikan air tawar, peternakan, air untuk mengairi pertanaman, dan atau peruntukan lain yang mempersyaratkan mutu air yang sama dengan kegunaan tersebut. Setelah didapatkan data hasil pengujian kualitas air sesuai dengan parameter yang telah ditetapkan, selanjutnya adalah perbandingan dengan Standar Baku Mutu Kualitas Air, dimana mengacu pada PP No. 82 Tahun 2001.

\subsection{Perhitungan Beban Pencemaran Sungai}

Berdasarkan Keputusan Menteri Negara Lingkungan Hidup Nomor 110 Tahun 2003 beban pencemaran adalah jumlah suatu unsur pencemar yang terkandung dalam air atau limbah. Terdapat batasan jumlah beban pencemar yang mampu diterima atau diperbolehkan oleh suatu perairan sesuai dengan kelas peruntukannya atau biasa disebut sebagai beban pencemar maksimum. Perhitungan ini dimaksudkan untuk mengetahui kondisi sungai masih mampu menerima beban pencemar atau tidak. Perhitungan beban pencemar maksimum dapat menggunakan persamaan berikut:

$$
\mathrm{BPM}=\mathrm{Q} \times \mathrm{C}_{\mathrm{BM}}
$$

Dimana: $\mathrm{BPM}=$ Beban pencemaran BOD dan DO maksimum (kg/hari), Q = Debit terukur ( $\mathrm{m}^{3} /$ detik), $\mathrm{C}_{\mathrm{BM}}=$ Konsentrasi (Standar baku mutu berdasarkan Peraturan Pemerintah No. 82/2001 tentang Pengelolaan Kualitas Air dan Pengendalian Pencemaran Air Kelas I) (mg/liter).

Beban pencemaran aktual adalah beban pencemaran yang dihasilkan di suatu sungai pada saat kondisi eksisting, rumus yang digunakan dalam menghitung beban pencemaran aktual sebagai berikut:

$$
\mathrm{BPA}=\mathrm{Q} \times \mathrm{C}_{\mathrm{M}}
$$

Dimana: BPA= Beban pencemaran BOD dan DO aktual $(\mathrm{kg} /$ hari $), \quad \mathrm{Q}=$ Debit terukur $\left(\mathrm{m}^{3} /\right.$ detik $), \mathrm{C}_{\mathrm{M}}=$ Konsentrasi terukur (mg/liter)

\subsection{Simulasi Kualitas Air Menggunakan Model Qual2E}

Permodelan penentuan daya tampung beban pencemaran menggunakan model Qual2E, karena dapat digunakan untuk mensimulasikan indikator pencemar sepanjang aliran sungai. Penggunaan model 
Qual2E sesuai dengan rekomendasi pada Keputusan Menteri Lingkungan Hidup Nomor 110 Tahun 2003 Tentang Pedoman Penetapan Daya Tampung Beban Pencemaran Air Pada Sumber Air pada suatu perairan. Model ini menggunakan perumusan matematika, perumusan digunakan untuk mengkomputasi macam-macam dari kesetimbangan air permukaan dan mensimulasikan perubahan dari kondisi aliran sepanjang sungai.

Hal pertama yang dilakukan dalam menggunakan aplikasi Qual2E adalah membagi subdivisi dari sistem yang dapat menggambarkan keragaman karakteristik hidrolik. Setiap sistem memiliki elemen komputasi dengan panjang yang sama. Sehingga, subdivisi yang telah dibagi dari sistem dapat memuat semua karakteristik sungai dengan komputasi elemen. Metode atau pemodelan dengan Qual2E adalah salah satu aplikasi yang digunakan untuk pemodelan pencemaran sungai yang dapat digunakan untuk mensimulasikan indikator pencemar sepanjang aliran sungai. Berdasarkan fungsi aplikasi Qual2E, dapat digunakan sebagai metode atau pemodelan untuk melakukan pemantauan kualitas air dan penentuan daya tampung beban pencemaran sebagai upaya pengelolaan kualitas air.

\subsection{Uji Kelayakan Model}

Validasi model dilakukan dengan kriteria statistic uji $\mathrm{x}^{2}$ (Kolmogorov-Smirnov) dimana kriteria kinerja model adalah rata-rata kuadrat simpangan dari residu (beda antara pengukuran lapangan dengan hasil model) yang dapat dijabarkan dengan persamaan berikut (Ferdinand, 2006):

$$
x^{2}=\sum_{r=1}^{n} \frac{(\text { nilai observasi }- \text { nilai model })^{2}}{\text { nilai model }}
$$

Dimana: $x^{2}=$ uji statistic rata-rata kuadrat dari simpangan, $\mathrm{n}=$ jumlah sampel, $\mathrm{r}=$ sampel ke- $\mathrm{n}$ Hasil perhitungan $\mathrm{x}^{2}$ ini kemudian dibandingkan dengan $\mathrm{x}^{2}$ dari tabel pada $\alpha=0,95$, apabila: $\mathrm{x}^{2}$ hitung $>$ $\mathrm{x}^{2}$ tabel, maka model ditolak $\mathrm{x}^{2}$ hitung $<\mathrm{x}^{2}$ tabel, maka model diterima

Koefisien determinasi menjelaskan proporsi variasi dalam variabel dependen $(\mathrm{Y})$ yang dijelaskan oleh hanya satu variabel independen (lebih dari satu variabel bebas: $\mathrm{Xi} ; \mathrm{i}=1,2,3$, 4, dst.) secara bersamasama (Sulaiman, 2004). Koefisien determinan berkisar antara nol sampai dengan satu $\left(0 \leq \mathrm{R}^{2} \leq 1\right)$. Hal ini berarti bila $\mathrm{R}^{2}=0$ menunjukkan tidak adanya pengaruh antara variabel independen terhadap variabel dependen, bila adjusted $\mathrm{R}^{2}$ semakin besar mendekati 1 menunjukkan semakin kuatnya pengaruh variabel independen terhadap variabel dependen dan bila adjusted $\mathrm{R}^{2}$ semakin kecil bahkan mendekati nol, maka dapat dikatakan semakin kecil pula pengaruh variabel independen terhadap variabel dependen. Rumus koefisien determinasi adalah sebagai berikut:

$$
K d=R^{2} \times 100 \%
$$

Dimana $: \mathrm{Kd}=$ Besar atau jumlah koefisien determinansi, $\mathrm{R}^{2}=$ Nilai koefisien korelasi. Sedangkan kriteria dalam melakukan analisis koefisien determinasi adalah sebagai berikut: jika $\mathrm{Kd}$ mendekati nol (0), berarti pengaruh variabel independen terhadap variabel dependen lemah, dan Jika Kd mendekati satu (1), berarti pengaruh variabel independen terhadap variabel dependen kuat.

\section{Hasil Dan Pembahasan}

\subsection{Kualitas Air Sungai Brantas}

Keseluruhan hasil uji kualitas air sungai Brantas dapat dilihat pada Gambar 2, berdasarkan hasil pengukuran suhu diperoleh bahwa keseluruhan lokasi memiliki suhu dengan interval suhu antara 25.6 - $25.9{ }^{\circ} \mathrm{C}$ (pada siang hari berkisar pukul 09.00 14.00). Menurut Wardhana (2004), air sungai yang suhunya naik akan menggangu kehidupan hewan air dan organisme air lainnya karena kadar oksigen yang terlarut dalam air akan turun bersamaan dengan kenaikan suhu. Menurut Fardiaz (1992), perubahan suhu berpengaruh terhadap proses fisika, kimia dan biologi badan air. Kenaikan suhu air akan menimbulkan beberapa akibat yaitu jumlah oksigen terlarut dalam air menurun, kecepatan reaksi kimia meningkat, kehidupan ikan dan hewan air lainnya tergangu dan jika batas suhu yang mematikan terlampaui, ikan dan hewan air lainnya mungkin akan mati.

Berdasarkan hasil pengukuran pH dari 12 lokasi sampling, keseluruhan $\mathrm{pH}$ sudah sesuai dengan baku mutu. Nilai $\mathrm{pH}$ tertinggi berada diT2 dengan nilai $\mathrm{pH}$ sebesar 8.3 yang bersifat basa dengan lokasi sampling berada di dekat bangunan RS UNISMA. Hal tersebut terjadi karena menurut Subekti (2011), kegiatan dari rumah sakit menghasilkan beberapa jenis limbah yaitu limbah padat, limbah cair maupun gas. Limbah cair rumah sakit merupakan limbah infeksius yang masih perlu pengelolaan sebelum dibuang ke lingkungan, hal ini dikarenakan limbah dari kegiatan rumah sakit tergolong limbah B3 yaitu limbah yang bersifat infeksius, radioaktif, korosif dan kemungkinan mudah terbakar. Basa tersebut dapat dihasilkan dari limbah rumah sakit yang bersifat korosif tersebut. Air limbah dan bahan buangan industri akan mengubah $\mathrm{pH}$ air yang pada akhirnya akan menggangu kehidupan organisme di dalam air (Wardhana, 2004). pH terendah berada di lokasi sampling ke enam dengan lokasi sungai yang terkontaminasi akibat limbah industri.

Kondisi oksigen terlarut pada keseluruhan lokasi sampling menunjukkan bahwa kadar DO paling rendah dengan nilai dibawah standar $4 \mathrm{mg} / \mathrm{L}$ adalah lokasi sampling keenam yang mendapatkan kontribusi pencemaran dari aktivitas industri rokok dan industri plastik. Kadar DO untuk keseluruhan lokasi masih relative memenuhi batas minimum kadar DO. Menurut Salmin (2005), oksigen memegang 
peranan penting sebagai indikator kualitas perairan, karena oksigen terlarut berperan dalam proses oksidasi dan reduksi bahan organik dan anorganik.

Kondisi BOD pada keduabelas lokasi sudah melampui standar baku mutu yang ditentukan. Apabila dibandingkan dengan kadar DO yang relatif memenuhi baku mutu hal ini menunjukkan kondisi oksigen dalam memnuhi kesegaran air sudah memenuhi, namun nilai BOD yang melebihi baku mutu menunjukkan bahwa kebutuhan oksigen untuk proses biologi masih relative kurang dikarenakan kebutuhan oksigen dalam membantu penguraian bahan organic secara kimia lebih besar. Berdasarkan definisi DO adalah kadar oksigen didalam perairan yang dapat dimanfaatakan mikroorganisme dalam mengurai bahan organic serta membantu proses penguraian bahan organic secara kimia. Kadar BOD paling tinggi berada di lokasi sampling ke enam dengan nilai $38 \mathrm{mg} / \mathrm{L}$, hal ini dikarenakan lokasi tersebut banyak menerima jenis pencemar dari kegiatan industri dan rumah sakit. Kartika et al, (2016), limbah cair industri rokok berasal dari limbah cengkeh (clove), limbah casing, dan limbah domestik. Pada masing-masing limbah tersebut rata-rata menghasilkan BOD sebesar 50-5.000 mg/L. Hal ini yang menyebabkan peningkatan yang signifikan pada parameter BOD. Pengukuran terendah yaitu pada T10 pada angka 6,660 mg/L, terletak pada kawasan Pasar Gadang yang merupakan pemukiman. Apabila dibandingkan dengan titik pengambilan sampel pada T6 yang mewakili industri rokok dan T10 yang mewakili limbah domestik, didapatkan hasil bahwa limbah rokok menghasilkan BOD yang lebih tinggi dibandingkan akibat dari adanya kegiatan pemukiman yang menghasilkan limbah domestik. Nilai BOD sungai Brantas masih relatif lebih kecil jika dibandingkan dengan penelitian (Zahroh 2019) BOD di Perairan Mundu untuk tahun 2015-2016 berkisar antara $16 \mathrm{mg} / \mathrm{l}-18.4 \mathrm{mg} / \mathrm{l}$. Perairan Suranenggala pada tahun 2015berkisar antara $15.3 \mathrm{mg} / \mathrm{l}$ - 16.4 mg/l dan mengalami peningkatan pada tahun 2016 yaitu $31.8 \mathrm{mg} / \mathrm{l}-33.9 \mathrm{mg} / \mathrm{l}$.

Perlakuan terhadap daerah yang memiliki kadar BOD sangat tinggi khususnya pada lokasi T6 adalah Perlu perhatian khusus untuk pembuangan limbah yang ada di perairan pada titik 6 agar dapat ditanggulangi dengan cepat dan tidak memperburuk kondisi yang ada. Industri rokok pada PERMENLH No. 01 Tahun 2010 Tentang Tata Laksana Pengendalian Pencemaran Air, termasuk dalam kegiatan sumber institusi. Program yang dilakukan untuk mengurangi beban pencemar yaitu dengan PROKASIH, dengan melakukan beberapa kegiatan. Kegiatan yang dilakukan diantaranya yaitu pengawasan, pembinaan dan sanksi atau penegakan hukum. Penegakan hukum disini dilakukan karena pada titik 6 yaitu pencemaran yang paling tinggi diantara titik yang lain. Sehingga perlu dilakukan pemantauan apabila terdapat ketidaksesuaian selanjutnya diberlakukan sanksi yang berlaku.
Kadar COD tertinggi juga ada dilokasi ke enam dengan nilai kadar COD sebesar 102 mg/L dengan selisih $77 \mathrm{mg} / \mathrm{L}$ dari standar baku mutu, sedangkan kadar COD lokasi lainnya di antara nilai 19-23 mg/L. Berbeda pada T9 yang terletak dekat dengan RSUD, sehingga peningkatan kadar COD yang ada dipengaruhi oleh limbah buangan dari rumah sakit. Faktor-faktor yang mempengaruhi COD yaitu oksigen terlarut, zat organik dan sumber pencemar lainnya. Kelarutan oksigen di dalam air, tergantung pada suhu, tekanan oksigen dalam atmosfer, serta kandungan garam dalam air. Kadar COD dalam air limbah akan berkurang seiring dengan berkurangnya konsentrasi bahan organik yang terdapat dalam air limbah (Boyd, 1990)

Kadar TSS pada keseluruhan lokasi masih dibawah standar baku mutu sehingga kadar sedimen di Sungai Brantas Kota Malang masih relative kecil. Berdasarkan hasil uji kandungan TSS diperoleh bahwa nilai tertinggi di lokasi sampling sembilan dengan kadar TSS sebesar $49 \mathrm{mg} / \mathrm{L}$ dan selisih dengan standar baku mutu berkisar $1 \mathrm{mg} / \mathrm{L}$ sehingga diperlukan upaya pengurangan potensi penambahan sedimen yang masuk ke badan air. Kadar TSS terendah berada di lokasi terakhir dengan nilai 6,267 mg/L. Besarnya kadar TSS dipengaruhi oleh banyak sedikitnya lahan terbuka disekitar badan air dan besarnya limpasan permukaan yang membawa sedimen ke badan air. Perbedaan yang terlihat pada grafik dikarenakan persebaran dari nilai TSS sendiri, menurut Winnarsih et al, (2016), tinggi nilai total suspended solid dipengaruhi oleh bahan-bahan tersuspensi yang berasal dari daratan yang terbawa oleh aliran sungai.

Kadar nitrat paling tinggi berada di T12 sebesar $26,150 \mathrm{mg} / \mathrm{L}$, hal ini dikarenakan terdapat pencemaran dari kegiatan pertanian sedangkan yang terendah sebesar 2,674 mg/L berada di T6 yang sumber pencemar didominasi oleh industri dan rumah sakit. Hampir keseluruhan lokasi memiliki kadar nitrat lebih besar dibandingkan standar baku mutu, sehingga perlu adanya upaya pengurangan aktivitas yang berpotensi memiliki kadar nitrat yang relative tinggi. Menurut Lihawa dan Mahmud (2017), nitrat di alam dapat dihasilkan secara alami maupun dari aktivitas manusia. Sumber alami nitrat adalah dari siklus nitrogen sedangkan sumber yang berasal dari kegiatan manusia adalah penggunaan pupuk nitrogen, limbah industri dan limbah organik. Jika manusia membuang kotoran dalam air, maka kadar nitrat akan meningkat. Kotoran banyak mengandung amoniak.

Hasil pengukuran parameter amonia menunjukkan bahwa T2, T3, T9, dan T12 masih dibawah standar baku mutu dan titik yang lain melebihi baku mutu. Standar baku mutu untuk parameter amonia yaitu $0,02 \mathrm{mg} / \mathrm{L}$ untuk perikanan. Terlihat perubahan yang sangat signifikan pada T6 yaitu pada angka 1,739 mg/L dimana pada titik yang lain hanya berkisar pada angka 0,01-0,05 mg/L. pada T6 yaitu titik berada pada kawasan industri rokok dan 
sangat mempengaruhi kondisi dari perairan di sekitarnya. Industri rokok mengandalkan cengkeh pada bahan baku pembuatannya, dimana cengkeh dapat menghasilkan limbah amonia yang tinggi.
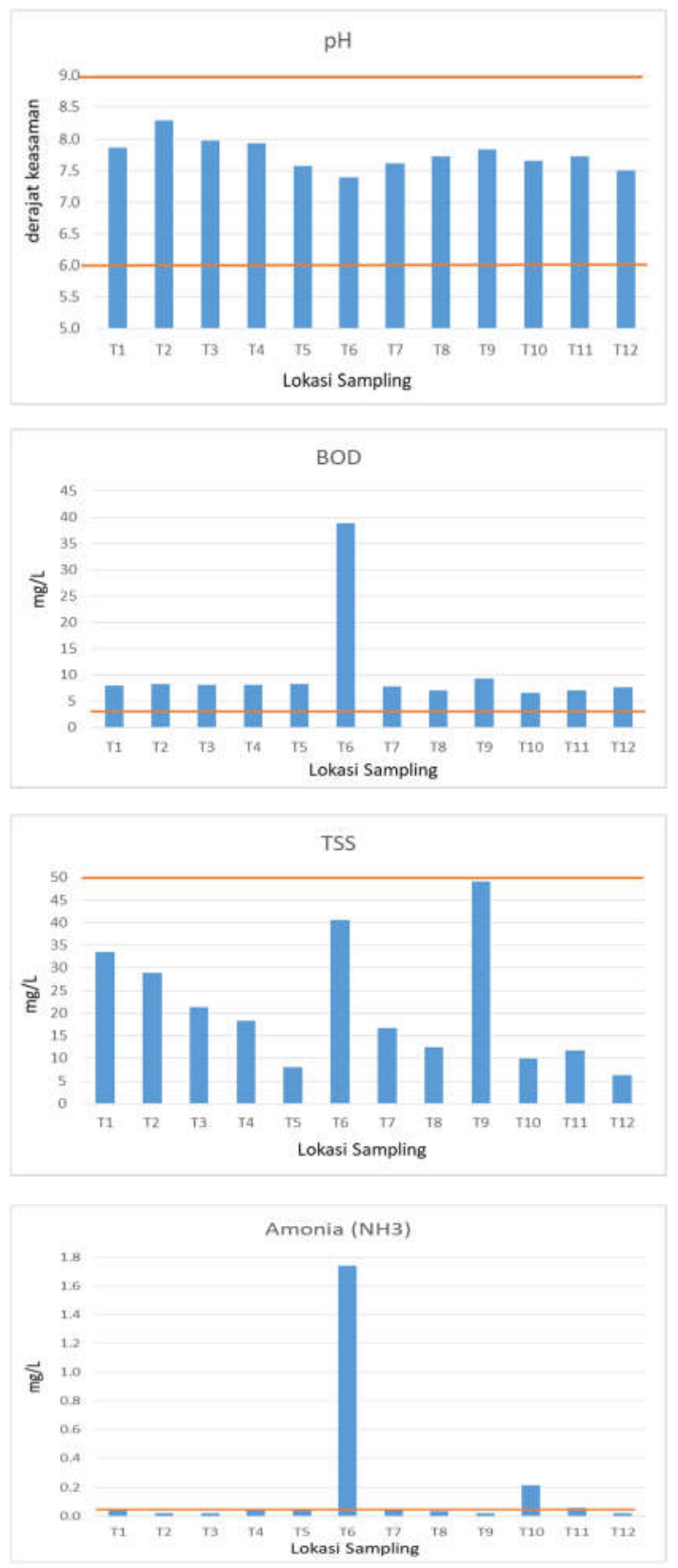

Menurut Kartika et al (2016), limbah cair industri rokok berasal dari limbah cengkeh (clove), limbah casing, dan limbah domestik.
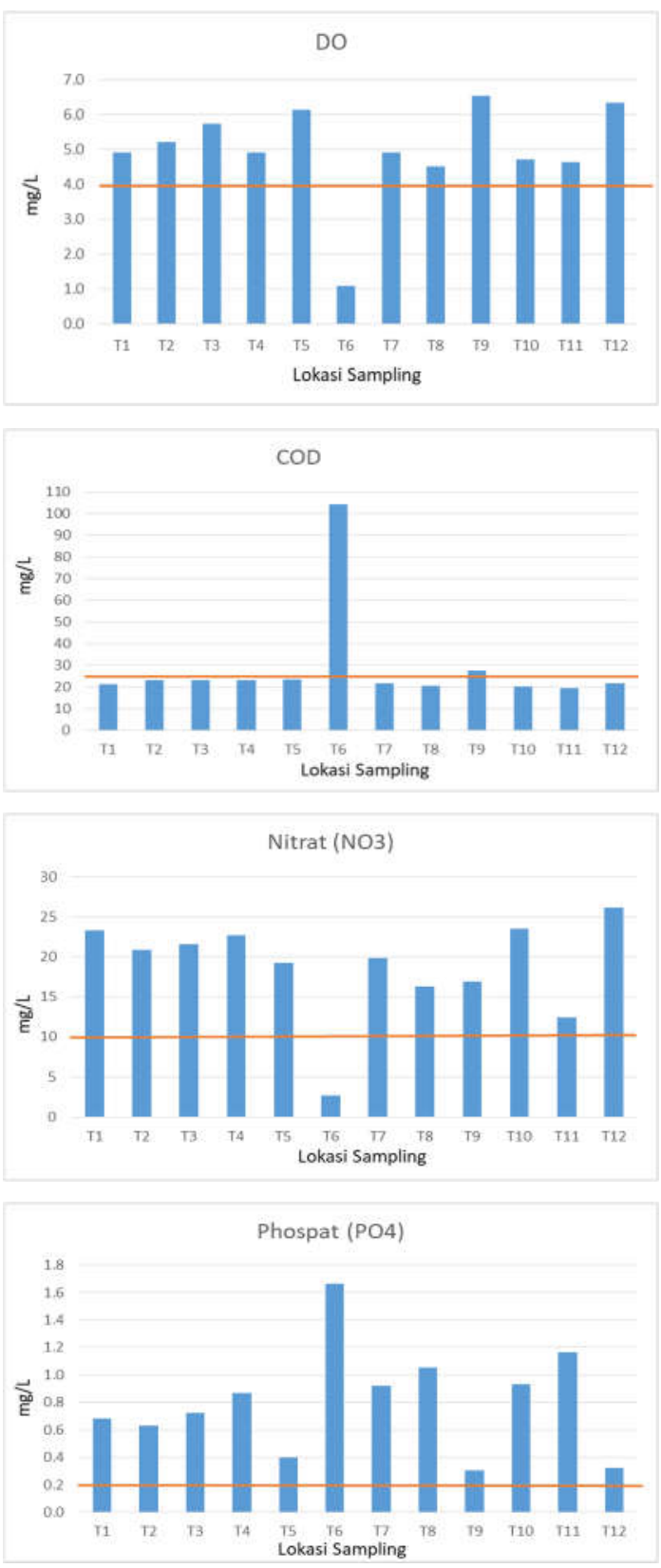

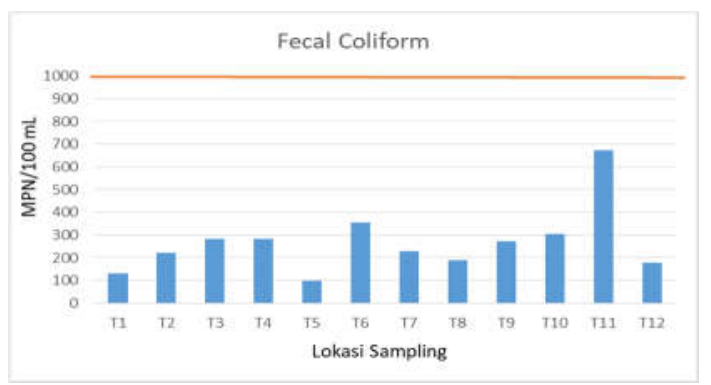

Gambar 3 Kualitas air sungai Brantas pada pengambilan sampel Bulan Agustus Tahun 2019

Berdasarkan hasil yang didapat, T1-12 melebihi baku mutu yang telah ditetapkan. Hasil kesuburan yang didapatkan berdasarkan tabel diatas yaitu tingkat kesuburan tertinggi pada T6 yaitu 1,663 mg/L. 
Angka yang didapatkan sangat jauh dari tingkat kesuburan "Sangat Subur Sekali" yaitu pada angka $>0.201 \mathrm{mg} / \mathrm{L}$. Hal ini dapat menyebabkan eutrofikasi yang tidak baik pada perairan, menurut Patty et al, (2015) apabila kedua zat ini konsentrasinya sangat besar di perairan dan melebihi ambang batas maka terjadi eutrofikasi yang ditandai dengan terjadinya blooming fitoplankton yang dapat menyebabkan kematian berbagai jenis biota laut.

Pengambilan titik pada T11 berada di lokasi pada RS Soepraoen, lokasi ini merupakan lokasi yang mewakilkan kegiatan domestik. Tingginya coli tinja pada titik ini dikarenakan limbah cair yang dihasilkan berdasarkan limbah kegiatan domestik karena padat penduduknya. Menurut Badan Pusat Statistik Malang dalam buku Kota Malang Dalam Angka Tahun 2016, kepadatan penduduk dalam visualisasi peta kepadatan penduduk Kota Malang angka terpadat pada Kecamatan Klojen yang diwakilkan oleh T11. Menurut Adrianto (2018), total bakteri koliform yang tinggi terdapat pada wilayah dengan kepadatan tempat tinggal penduduk, sehingga banyak kegiatan yang dilakukan di sekitar sungai tersebut antara lain untuk mandi dan mencuci pakaian. Pengaruh limbah rumah tangga seperti feses atau sisa makanan lainnya masih mendominasi sebagai faktor penyebab pencemaran lingkungan air.

\subsection{Simulasi Kualitas Air Menggunakan Qual2E}

Pada simulasi penentuan beban pencemaran menggunakan software Qual2E hanya menghasilkan parameter DO dan BOD, hal ini dikarenakan simulasi menggunakan feature Command Program dengan bentuk file data yang digunakan adalah berupa notepad (.txt) dan hasil running juga dalam bentuk yang sama. Simulasi menggunakan model Qual2E diawali dengan memasukkan data tiap segmen meliputi data iklim dan data lokasi pengambilan sampel (longitude dan latitude). Selanjutnya adalah input data terkait dengan pembagian jarak, temperatur dan debit tiap segmen, setelah itu kemudian memasukkan data BOD dan DO pada kolom initial condition. Langkah terakhir adalah menentukan salah satu segmen sebagai headwater, point source.

Setelah input data, baru kita dapat melakukan running program. Pastikan data yang terisi sesuai dengan format yang ditentukan. Pada penelitian ini penggunakan model Qual2E digunakan pada parameter DO dan BOD. Hasil visualisasi atau simulasi dari Qual2E untuk parameter BOD dan DO dapat dilihat pada Gambar 4.

Pembacaan grafik hasil simulasi adalah pada bagian bawah ditarik ke atas dengan melihat simbol “*” dan di bagian kiri adalah jarak sungai untuk parameter BOD. Pada bagian atas ditarik ke bawah dengan simbol “.” Pada bagian kiri merupakan jarak sungai untuk parameter DO. Visualisasi simulasi pada parameter BOD dan DO menggunakan software Qual2E menunjukkan angka yang berbeda dengan pengujian pada laboratorium. Namun menunjukkan kecenderungan yang sama dimana semakin ke hilir nilai BOD menunjukkan nilai meningkat, sedangkan untuk parameter DO kecenderungan menurun pada jarak 3.2 - $6.4 \mathrm{~km}$ sedangkan setelah jarak tersebut menunjukkan nilai DO yang meningkat. Perbedaan angka pada hasil simulasi Qual2E akan dibandingkan dengan angka hasil pengujian laboratorium pada Gambar 3 untuk mendapatkan kelayakan penggunakan model Qual2E dalam memodelkan kualitas air khususnya di Sungai Brantas Kota Malang.

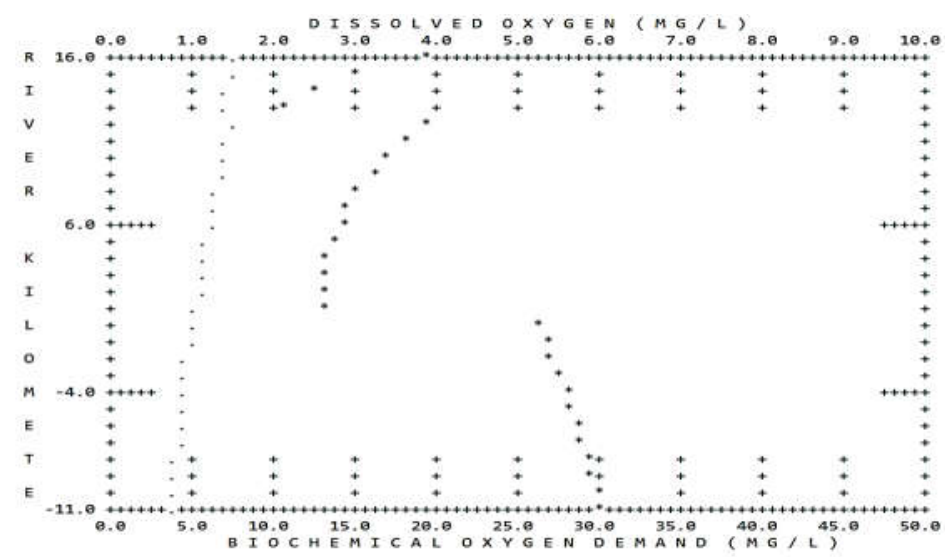

Gambar 4 Visualisasi Simulasi BOD dan DO Menggunakan Software Qual2E

Hasil simulasi dari Qual2E perlu dilakukan uji validasi dengan membandingkan hasil uji simulasi terhadap hasil uji laboratorium. Metode yang digunakan untuk menguji hasil simulasi adalah melalui nilai $\mathrm{R}^{2}$ untuk mengetahui kedekatan hubungan antara hasil uji dan hasil simualsi serta nilai $\mathrm{x}^{2}$ untuk mengetahui kesalahan hasil simulasi masih dapat diterima atau ditolak. Tabel 3 dan Gambar 5 merupakan hasil uji validasi terhadap hasil simulasi menggunakan Qual2E. Hasil uji validasi menunjukkan bahwa nilai $x^{2}$ hitung masih lebih kecil dibandingkan $\mathrm{x}^{2}$ pada Tabel sehingga hasil model dapat diterima, kemudian berdasarkan uji $\mathrm{R}^{2}$ menunjukkan bahwa hasil model dan hasil uji menunjukkan hubungan kedekatan dengan nilai $\mathrm{R}^{2}$ pada BOD adalah $74 \%$ dan pada parameter DO adalah $64 \%$. 
Tabel 3 Uji validasi Chi Square hasil uji Qual2E BOD (a) dan DO (b)

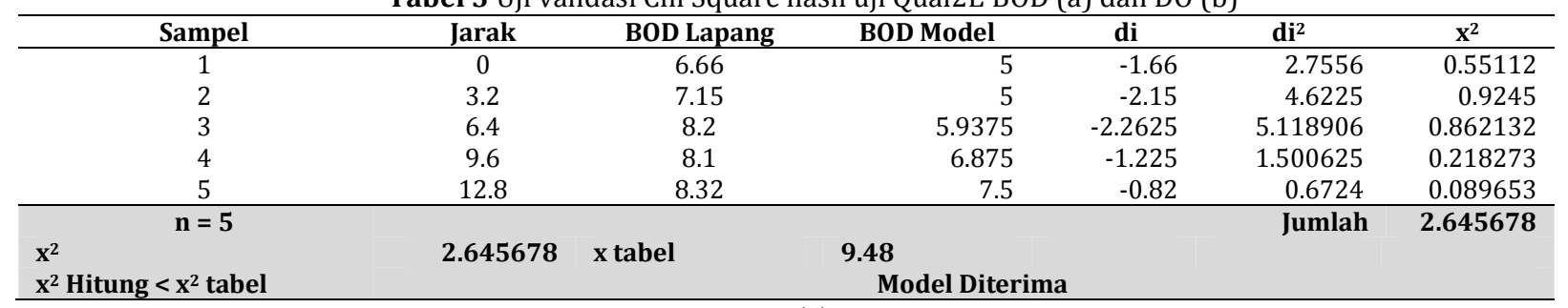

(a)

\begin{tabular}{|c|c|c|c|c|c|c|}
\hline Sampel & Jarak & DO Lapang & DO Model & di & $d^{2}{ }^{2}$ & $\mathbf{x}^{2}$ \\
\hline 1 & 0 & 4.7 & 6.5 & 1.8 & 3.24 & 0.498462 \\
\hline 2 & 3.2 & 4.5 & 5 & 0.5 & 0.25 & 0.05 \\
\hline 3 & 6.4 & 4.9 & 5.125 & 0.225 & 0.050625 & 0.009878 \\
\hline 4 & 9.6 & 5.73 & 7.5 & 1.77 & 3.1329 & 0.41772 \\
\hline 5 & 12.8 & 5.2 & 7 & 1.8 & 3.24 & 0.462857 \\
\hline$n=5$ & & & & & Jumlah & 1.438917 \\
\hline $\begin{array}{l}x^{2} \\
x^{2} \text { Hitung }<x^{2} \text { tabel }\end{array}$ & 1.438917 & $x$ tabel & $\begin{array}{l}9.48 \\
\quad \text { Model Dit }\end{array}$ & & & \\
\hline
\end{tabular}

(b)
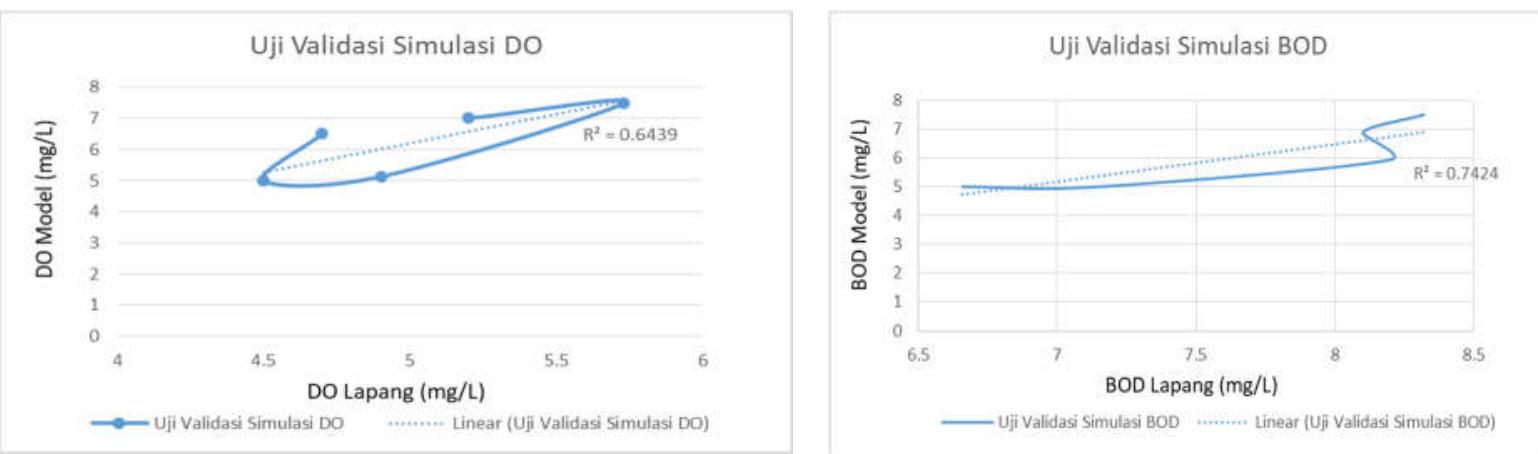

Gambar 5 Hasil uji validasi R² simulasi DO dan BODmenggunakan Qual2E

\subsection{Penentuan Daya Tampung Beban Pencemaran Berdasarkan Kadar BOD}

Berdasarkan hasil perhitungan beban pencemaran actual pada keseluruhan lokasi, T1 sudah tidak mampu lagi menerima beban pencemar dengan kandungan BOD. Rata-rata beban pencemar BOD yang diterima oleh T1 berkisar $25.19 \mathrm{~kg} /$ hari sedangkan batas maksimal beban pencemar yang diterima sebesar $32.32 \mathrm{~kg} /$ hari. T1 mendapatkan polutan dari kegiatan rumah sakit. T2 memiliki beban pencemar yang lebih rendah dibandingkan dengan T1 dimana rata-rata beban pencemar yang diterima secara keseluruhan $8.63 \mathrm{~kg} /$ hari dan kadar maksimum yang diterima sebesar $11.09 \mathrm{~kg} / \mathrm{hari}$. Parameter yang diterima berlebih di lokasi ini adalah BOD dengan kadar yang diterima melebihi $4.1 \mathrm{~kg} /$ hari. Titik 2 berada pada daerah dekat dengan industri rumah sakit dan pemukiman seperti pada titik sebelumnya. Hal ini dapat menjadi penyebab terlampauinya daya tampung pada parameter BOD rumah sakit. Pembuangan limbah perlu dilakukan pemantauan yang lebih karena apabila dibiarkan secara terusmenerus akan mengalami akumulasi yang meningkat setiap harinya dan daya tampung akan mengalami penurunan sehingga akan memperburuk kondisi yang ada.
T3 dengan sumber pencemar dari industri rokok dan plastic dengan parameter yang melebihi beban maksimum yaitu parameter BOD dengan kadar yang berlebih sebesar $0.4 \mathrm{~kg} / \mathrm{hari}$, Rata-rata beban pencemar yang diterima sebesar $0.85 \mathrm{~kg} / \mathrm{hari}$ sedangkan beban pencemar maksimum yang diijinkan sebesar $1.01 \mathrm{~kg} / \mathrm{hari}$, sehingga secara keseluruhan masih dapat menerima beban pencemar. Lokasi pengambilan berada dekat dengan pemukiman sehingga faktor yang mempengaruhi yaitu limbah domestik hasil dari kegiatan masyarakat yang ada di sekitar perairan. Pemerintah perlu melakukan program untuk penurunan beban pencemar untuk kegiatan domestik sebagai upaya pengelolaan daya tampung sungai. Program yang diterapkan yaitu penerapan penyediaan IPAL (Instalasi Pengolahan Air Limbah) Komunal.

T4 merupakan lokasi badan air yang menerima polutan dari industri rokok dimana berdasarkan perhitungan daya tampung beban pencemaran diperoleh bahwa parameter yang berlebih adalah parameter BOD dengan nilai $8.5 \mathrm{~kg} /$ hari. Rata-rata beban pencemar actual yang diterima lokasi ini adalah $18.17 \mathrm{~kg} /$ hari dengan beban pencemar rata-rata maksimum sebesar $23.24 \mathrm{~kg} /$ hari. Kegiatan rumah sakit dan pemukiman yang ada di sekitar perairan sangat mempengaruhi daya tampung perairan, maka 
dari itu perlu adanya peninjauan terhadap limbah yang dibuang.

T5 merupakan lokasi badan air yang menerima pencemaran dari rumah sakit dan industri dan merupakan lokasi yang menerima akumulasi pencemaran dari titik pertama sampai ke empat namun jumlah pencemar yang diterima lebih kecil. Hal ini dikarenakan adanya penambahan debit air dari anak sungai lain dan bahan pencemar sudah tereduksi dengan adanya penambahan jarak aliran air. Beban pencemaran rata-rata yang diterima oleh lokasi ini adalah $4.45 \mathrm{~kg} /$ hari dan beban rata-rata maksimum yang dapat diterima adalah sebesar $5.72 \mathrm{~kg} / \mathrm{hari}$. Kadar yang melebihi batas maksimum untuk diterima lokasi sungai ini adalah BOD dengan kadar berlebih sebesar $2.09 \mathrm{~kg} /$ hari. Pada titik ini bersumber dari industri cat dan limbah domestik warga sekitar. Lokasi pengambilan dan kegiatan yang ada disekitar perairan dapat mempengaruhi yaitu berasal dari limbah domestik dan limbah industri hasil dari kegiatan masyarakat yang ada di sekitar perairan.

T6 merupakan lokasi dengan kualitas air paling buruk dikarenakan lokasi tersebut merupakan akumulasi beban pencemaran dari T2 dan kelima sebelumnya. Aktivitas sumber pencemar pada lokasi ini didominasi oleh limbah domestic dari kegiatan pemukiman, selain itu aktivitas rumah sakit dan industri juga berkontribusi ke dalam pencemaran pada lokasi ini. Rata-rata beban pencemar yang diterima relative paling besar dibandingkan lokasi sebelumnya yaitu berkisar antara $33.79 \mathrm{~kg} / \mathrm{hari}$ dengan nilai rata-rata maksimum adalah 43.41 $\mathrm{kg} /$ hari. Parameter kualitas air yang sudah terlampui jumlah yang diterima adalah BOD dengan nilai 16.08 $\mathrm{kg} /$ hari. Sumber pencemar pada titik pengambilan 6 yaitu berasal dari industri rokok karena pengambilan dilakukan pada daerah kawasan industri rokok. Industri rokok pada PERMENLH No. 01 Tahun 2010 Tentang Tata Laksana Pengendalian Pencemaran Air, termasuk dalam kegiatan sumber institusi. Program yang dapat dilakukan untuk mengurangi beban pencemar yaitu dengan PROKASIH, dengan melakukan beberapa kegiatan. Kegiatan yang dilakukan diantaranya yaitu pengawasan, pembinaan dan sanksi atau penegakan hukum.

T7 merupakan lokasi yang menerima sumber pencemar dari satu jenis aktivitas industri dan domestic. Beban pencemar yang diterima cukup besar dibandingkan dengan 6 lokasi sebelumnya. Kontribusi dari industri tersebut sangat besar sehingga jumlah beban pencemar yang diterima relative tinggi. Beban rata-rata pencemar yang diterima sebesar 98.79 $\mathrm{kg} /$ hari dan beban rata-rata maksimum 126.90 $\mathrm{kg}$ /hari. Kadar yang berlebih dalam air adalah BOD sebesar $46.56 \mathrm{~kg} /$ hari. Pada titik ini serupa dengan titik sebelumnya yaitu dekat dengan industri rokok.

T8 merupakan lokasi yang menerima beban pencemar dengan dominasi dari aktivitas rumah sakit, terdapat 3 rumah sakit yang berpotensi membuang limbah di daerah ini. Rata-rata beban yang diterima oleh lokasi ini sebesar $11.95 \mathrm{~kg} /$ hari dan rata-rata beban maksimum yang diterima sebesar $15.3 \mathrm{~kg} / \mathrm{hari}$. Parameter yang berlebih dikandungan air adalah BOD dengan nilai $5.68 \mathrm{~kg} /$ hari. Sumber pencemar pada titik pengambilan 8 berasal dari akumulasi kegiatan rumah sakit dan pemukiman yang ada. Limbah buangan dari industri rumah sakit dan limbah domestik dapat mempengaruhi daya tampung yang ada pada perairan ini. Daya tampung yang terlampaui jumlah nya masih sedikit dibandingkan dengan tiitk yang sebelumnya. Walaupun demikian, tetap perlu perhatian khusus agar tidak memperburuk keadaan yang terjadi.

T9 didominasi sumber pencemar dari aktivitas industri yang berada di Kecamatan Sukun, terdapat dua pabrik besar yang berpotensi membuang limbah cair ke sungai tersebut. Beban pencemaran rata-rata yang diterima lokasi tersebut sebesar $124.7 \mathrm{~kg} /$ hari dan rata-rata beban maksimum adalah sebesar 159.6 $\mathrm{kg} /$ hari. Parameter yang berlebih dalam kandungan air adalah BOD dengan kadar $59.62 \mathrm{~kg} / \mathrm{hari}$. T9 merupakan lokasi yang berada pada daerah persawahan dan perkebunan. Pada PERMENLH No. 01 Tahun 2010 Tentang Tata Laksana Pengendalian Pencemaran Air, penurunan beban pencemar dapat dilakukan untuk kegiatan pertanian yaitu dengan program Green Farming. Kegiatan yang dilakukan untuk mendukung program penurunan beban pencemar yaitu pembinaan dan penyuluhan.

T10 merupakan lokasi akumulasi pencemaran dari titik 1, 2, 5, dan 6 dengan sumber pencemar dari aktivitas domestic, rumah sakit dan industri. Beban pencemar rata-rata yang diterima dilokasi ini sebesar $3.89 \mathrm{~kg} /$ hari dan rata-rata beban maksimum yang diterima lokasi tersebut adalah sebesar $4.966 \mathrm{~kg} / \mathrm{hari}$. Parameter yang berlebih pada parameter BOD sebesar $1.89 \mathrm{~kg} /$ hari. T11 merupakan lokasi dengan sumber pencemar rumah sakit, industri dan pemukiman di Kecamatan Kedungkandang. Beban rata-rata actual yang diterima lokasi ini adalah sebesar $48.54 \mathrm{~kg} /$ hari sedangkan rata-rata beban maksimum yang dibolehkan adalah sebesar 62.43 $\mathrm{kg} /$ hari. Parameter-parameter yang melebihi batas maksimum adalah BOD dengan nilai $22.69 \mathrm{~kg} /$ hari.

Kadar rata-rata beban pencemar actual yang diterima pada T12 sebesar $56.35 \mathrm{~kg} /$ hari dan ratarata beban maksimum yang diijinkan sebesar 72 $\mathrm{kg} /$ hari. Parameter yang berlebih di dalam kandungan air adalah BOD sebesar $25.75 \mathrm{~kg} /$ hari. Lokasi pengambilan sampel yang berada pada jaringan sungai setelah industri yang dapat mempengaruhi nilai dari indeks pencemaran tersebut.

Keseluruhan lokasi sampling pada penelitian ini menunjukkan nilai BOD yang sudah melampui baku mutu hal ini juga terjadi pada penelitian Rahayu et al, 2018 kajian perhitungan beban pencemaran air sungai di DAS Cikapundung dengan dominasi aktivitas adalah pemukiman. Bahkan ditemukan hasil bahwa beban pencemaran BOD yang diterima meningkat setiap tahun. 
Tabel 5 Daya tampung beban pencemaran sungai Brantas Kota Malang

\begin{tabular}{cccc}
\hline \multirow{2}{*}{ Lokasi } & \multicolumn{3}{c}{ BOD } \\
\cline { 2 - 4 } & BPA $(\mathrm{kg} / \mathrm{hari})$ & BPM $(\mathrm{kg} / \mathrm{hari})$ & DTBP $(\mathrm{kg} / \mathrm{hari})$ \\
\hline T1 & 19.23783 & 7.360542 & -11.8773 \\
T2 & 6.629006 & 2.525158 & -4.10385 \\
T3 & 0.652522 & 0.251011 & -0.40151 \\
T4 & 13.83345 & 5.320784 & -8.51267 \\
T5 & 3.397506 & 1.302048 & -2.09546 \\
T6 & 25.96297 & 9.884255 & -16.0787 \\
T7 & 75.45538 & 28.89754 & -46.5578 \\
T8 & 9.169327 & 3.483976 & -5.68535 \\
T9 & 95.96571 & 36.34286 & -59.6229 \\
T10 & 3.030353 & 1.131055 & -1.8993 \\
T11 & 36.90822 & 14.21625 & -22.692 \\
T12 & 42.31455 & 16.57263 & -25.7419 \\
\hline Keterangan: & & &
\end{tabular}

$\mathrm{BPA}=$ Beban pencemaran actual, $\mathrm{BPM}=$ Beban pencemaran maksimum, $\mathrm{DTBP}=$ Daya tampung beban pencemaran

\section{Kesimpulan}

Berdasarkan hasil analisa yang diperoleh, dapat disimpulkan bahwa semakin ke hilir pola kadar DO Sungai Brantas Kota Malang semakin menurun dan kadar BOD yang meningkat, hal ini menunjukkan penurunan kualitas air sungai pada daerah hilir. Sungai Brantas Kota Malang sudah tidak mampu menerima beban pencemaran dengan kadar BOD yang tinggi karena kadar BOD pada Sungai Brantas Kota Malang sudah melampui batas kemampuan peruntukan. Simulasi kondisi kualitas air Sungai Brantas Kota Malang menggunakan Qual2E menghasilkan tingkat hubungan dengan data uji laboratorium sebesar 64\% untuk DO dan 74\% untuk BOD, sedangkan berdasarkan uji chi square penggunaan model Qual2E dapat diterima dengan hasil $\mathrm{x}^{2}$ hitung lebih kecil dari $\mathrm{x}^{2}$ tabel.

\section{DAFTAR PUSTAKA}

[KLHK] Kementrian Lingkungan Hidup. 2003. Pedoman Penetapan Daya Tampung Beban Pencemaran Air pada Sumber Air. Kementerian Lingkungan Hidup, Jakarta.

[KLHK] Kementrian Lingkungan Hidup. 2010. Tata Laksana Pengendalian Pencemaran Air. Kementerian Lingkungan Hidup, Jakarta.

[Pemetintah Republik Indonesia] Pemerintah Republik Indonesia Nomor 82. 2001. Pengelolaan Kualitas Air dan Pengendalian Pencemaran Air. Lembaran Negara RI Tahun 2001, No.153. Jakarta: Sekretariat Negara.

[Pemerintah gubernur Jawa Timur] Peraturan Gubernur Jawa Timur Nomor 61. 2010. Pedoman Tentang Penetapan Kelas Air Pada Air Sungai.

[Pemerintah Daerah Provinsi Jawa Timur] Dinas Lingkungan Hidup. 2016. Ringkasan Eksekutif Informasi Kinerja Pengelolaan Lingkungan Hidup Daerah Provinsi Jawa Timur Tahun 2016.

Adrianto, Rizki. 2018. Pemantauan Jumlah Bakteri Coliform di Perairan Sungai Provinsi Lampung. Majalah Teknologi Agro Industri (Tegi). 10 (1): 1-6. Bandar Lampung: Balai Riset dan Standardisasi Industri Bandar Lampung.

Boyd, C.E., 1990. Water Quality in Ponds for Aquaculture.Birmingham Publishing Co. Birmingham, Alabama.

Damarany P, Melati F F, Widyo A. 2009. Kajian Kualitas Air Sungai Cipinang Bagian Hilir Ditinjau dari Parameter
BOD dan DO Menggunakan Model Qual2E. Jurnal Teknologi Lingkungan Vol. 5 NO. 2. ISSN: 1829-6572 pp 62-74.

Fahmi .Y A, Hardini, Hevi. K dan Tri. S. 2018. Nnovative Governance Dalam Pengelolaan Sampah Berbasis Social Empowertment Pada Pemerintah. LOGOS Journal of Local Government Issues. Malang: Universitas Muhammadiyah Malang.

Fajarudin A H, M Solikin, Tri B P. 2017. Studi Penentuan Daya Tampung Beban Pencemaran Sungai Brantas Ruas Kota Malang dengan Menggunakan Paket Program Qual2Kw. Skripsi. Malang: Universitas Brawijaya.

Fardiaz, S. 1992. Polusi Air dan Udara. Penerbit Kanisius. Yogyakarta.

Ferdinand, A. 2006. Structural Equation Modeling Dalam Penelitian Manajemen (Aplikasi Model-Model Rumit Dalam Penelitian untuk Tesis Magister \& Disertasi Doktor). Semarang: BP Universitas Diponegoro.

Handayani. ST, Suharto. B, Marsoedi. 2001. Penentuan status kualitas perairan sungai brantas hulu dengan biomonitoring makrozoobentos: tinjauan dari pencemaran bahan organik. Biosain. 1(1):30-38

Kartika, Dita, Nurjazuli dan Budiyono. 2016. Kemampuan Serbuk Biji Asam Jawa dalam Menurunkan TSS, Trubiditas, dan Amoniak Pengolahan Limbah Cair PT. Utama Multiniaga Indonesia. Jurnal Kesehatan Masyarakat. 4 (4): 917-924. Semarang: Universitas Diponegoro.

Lihawa. F, dan Marike. M. 2017. Evaluasi Karakteristik Kualitas Air Danau Limboto. Jurnal Pengelolaan Sumberdaya Alam dan Lingkungan. 7 (3): 260-266. Gorontalo: Universitas Negeri Gorontalo.

Mahfud. M, Lihawa. F, Iyabu. H, Sakakibara. M. 2014. Kajian Pencemaran Merkuri terhadap Lingkungan di Kabupaten Gorontalo Utara. Skripsi. Gorontalo: Universitas Negeri Gorontalo.

Mahyudin. S, dan Tri. B P. 2015. Analisis Kualitas Air Dan Strategi Pengendalian Pencemaran Air Sungai Metro di Kota Kepanjen Kabupaten Malang. J-PAL. Vol. 6. No. 2. Malang: Universitas Brawijaya.

Parveen. N, dan SK. Singh. 2016. Application of Qual2E Model for River Water Quality Modelling. International Journal of Advance Research and Innovation. Volume 4, Issue 2: 429-432. Delhi Technological University, New Delhi, India.

Patty, Simon. I, Hairati. A, dan Malik. S. A. 2015. Zat Hara (Fosfat, Nitrat), Oksigen Terlarut dan pH Kaitannya dengan Kesuburan di Perairan Jikumerasa, Pulau 
Buru. Jurnal Pesisir dan Laut Tropis. 1 (1): 43-50. Ambon: LIPI.

Rahayu Y, Iwan J, Dyah M. 2018. Kajian Perhitungan Beban Pencemaran Air Sungai Di Daerah Aliran Sungai (DAS) Cikapundung dari Sektor Domestik. Jurnal Rekayasa Hijau Vol 2. No.1 pp 61-71.

Salmin. 2005. Oksigen Terlarut (DO) Dan Kebutuhan Oksigen Biologi (BOD) Sebagai Salah Satu Indikator Untuk Menentukan Kualitas Perairan. Oseana. XXX (3): 21-26. Jakarta: LIPI.

Sulaiman, W. 2004. Analisis Regresi Menggunakan SPSS. Yogyakarta: Penerbit Andi.

Utama, JP. 2015. Daya Tampung Beban Pencemaran Sungai Dengan Judul Penentuan Daya Tampung Beban Pencemaran BOD Dan Fecal Coliform Sungai Plumbon Kota Semarang Dengan Software QUAL2E. Jurnal Teknik Lingkungan. Semarang: Universitas Diponegoro.
Wardhana, W.A. 2004. Dampak Pencemaran Lingkungan. Edisi Revisi. Andi Offset. Yogyakarta.

Winnarsih. E, dan La Ode. A. A. 2016. Distribusi Total Suspended Solid Permukaan di Perairan Teluk Kendari. Sapa Laut. 1 (2): 54-59. Kendari: Universitas Halu Oleo.

Wiwoho. 2005. Model Identifikasi Daya Tampung Beban Cemaran Sungai Dengan Qual2e (Study Kasus Sungai Babon). Thesis. Semarang: Universitas Diponegoro.

Yulianti, U. 2011. Faktor-Faktor Yang Mempengaruhi Konsumen Dalam Pembelian Makanan Jajan Tradisional Di Kota Malang. Skripsi. Malang: Universitas Muhammadiyah Malang.

Zahroh. A, Etty. R, Syaiful. A. 2019. Analisis Kualitas Perairan Untuk Budidaya Kerang Hijau Di Kabupaten Cirebon Provinsi Jawa Barat. Jurnal Pengelolaan Sumberdaya Alam dan Lingkungan Vol. 9 No 1: 86-91. 